\title{
Spatial distribution of Cynips quercusfolii (Hymenoptera: Cynipidae) galls on leaves and within the crowns of oak trees
}

\author{
Marian J. GIERTYCH ${ }^{1,2}$, Andrzej M. JAGODZIŃSKI ${ }^{1,3}$ and Piotr KAROLEWSKI ${ }^{1}$ \\ ${ }^{1}$ Polish Academy of Sciences, Institute of Dendrology, Parkowa 5, 62-035 Kórnik, Poland \\ ${ }^{2}$ University of Zielona Góra, Faculty of Biological Sciences, Szafrana 1, 65-516 Zielona Góra, Poland; \\ e-mail: giertych@man.poznan.pl \\ ${ }^{3}$ Poznań University of Life Sciences, Faculty of Forestry, Department of Forest Protection, Wojska Polskiego 71c, 60-625 Poznań, \\ Poland; e-mail: amj@man.poznan.pl
}

Key words. Hymenoptera, Cynipidae, Cynips quercusfolii, galls, oaks, gall distribution, oviposition preference

\begin{abstract}
The factors that affect oviposition and consequently spatial distribution of the galls of many gall makers are poorly understood. Knowledge of these factors could result in a better understanding of the mechanisms that initiate and regulate the development of galls. We tested the hypotheses that, regardless of tree height, galls of Cynips quercusfolii L. produced agamically are distributed randomly in the crowns and on the veins of leaves of oak trees. This study was done in Poland on 15 pedunculate oak (Quercus robur) trees of various heights. We measured the areas of 1659 leaves, including 192 leaves with galls, and the distances along a vein from a gall to the petiole and from gall to leaf edge. The number of galls did not depend on tree height but depended on the position of the leaf within the crown (upper or lower). Regardless of the position in the crown, leaves with galls were significantly larger than those without galls. We conclude that galls were located at a fixed distance from the edge of leaves irrespective of leaf size, but the distance from the gall to the leaf petiole depended significantly on leaf size. We conclude that agamic females of $C$. quercusfolii prefer large leaves and choose the site on a leaf on which to deposit their eggs. This probably ensures that the developing gall obtains the required amount of nutrients and assimilates.
\end{abstract}

\section{INTRODUCTION}

Trees of the genus Quercus (Fagaceae) host numerous insect species that form galls, however, the biology of gall-forming insects and their interactions with host plants are still poorly understood. Oviposition and the development of galls can depend on many factors, such as phenology of the host species (Karban, 2007; Hood \& Ott, 2010), diversity and quality of food (Horner \& Abrahamson, 1992; Abrahamson et al., 2003; Kuczynski \& Skoracka, 2005; Nyman et al., 2011), risk of parasitism and predation (Sitch et al., 1988; Poff et al., 2002) and over wintering site (Skuhravy \& Skuhrava, 1996). The location of galls on leaf surfaces is related directly to oviposition, but the factors that affect the choice of oviposition site by females remain unresolved. Describing spatial distribution patterns of the galls is a necessary first-step in identifying and investigating possible factors that determine oviposition and hence fitness of the gall-forming insect.

Kampichler \& Teschner (2002) presumed that poor knowledge of basic ecological factors determining the spatial patterns of common gall-formers results from the limited possibilities for collecting data from the crowns of trees. We analyzed all of the leaves on several oaks in order to determine the spatial distribution of the galls of the agamic generation of the oak gall wasp Cynips quercusfolii L. (Hymenoptera: Cynipidae). This species has a heterogonic life cycle (Folliot, 1964; Pujade-Villar et al., 2001). In central Europe, the first (agamic) generation females appear in late autumn or winter and oviposit in dormant lateral buds of oak (Kolk et al., 1996). In spring small red galls grow from these buds. Second generation females and males emerge from these galls in early summer (June). Soon after their emergence, the females insert fertilized eggs into the veins on the underside of oak leaves, which develop in summer into large spherical galls with a single chamber. Galls with pupae or mature females fall with the leaves in autumn (Kolk et al., 1996).

The spatial distribution of $C$. quercusfolii galls with respect to the level within the crowns of trees and location on leaves is unknown. Some information on gall location is given by Zargaran et al. (2011), who showed that geographical location within crowns of trees had a significant influence on gall size. Larval survival is greater in large than small galls because they provide a greater supply of food and better protection against enemies. We tested the hypotheses that: (1) galls produced by the agamic generation of $C$. quercusfolii are evenly distributed in the upper and lower parts of the crowns of oak independently of tree height, (2) occurrence of galls is not related to the size of the leaves and (3) the distribution of galls on surfaces of leaves is random.

\section{MATERIAL AND METHODS}

This study was carried out in a forest complex in Central Poland $\left(51^{\circ} 48^{\prime} \mathrm{N} ; 17^{\circ} 06^{\prime} \mathrm{E}\right)$ in four stands of pedunculate oak (Quercus robur L.) trees of various ages $(37,50,79$, and 95 years old) in the middle of July 2008. In each stand, eight trees had been cut down for other purposes, which presented the 


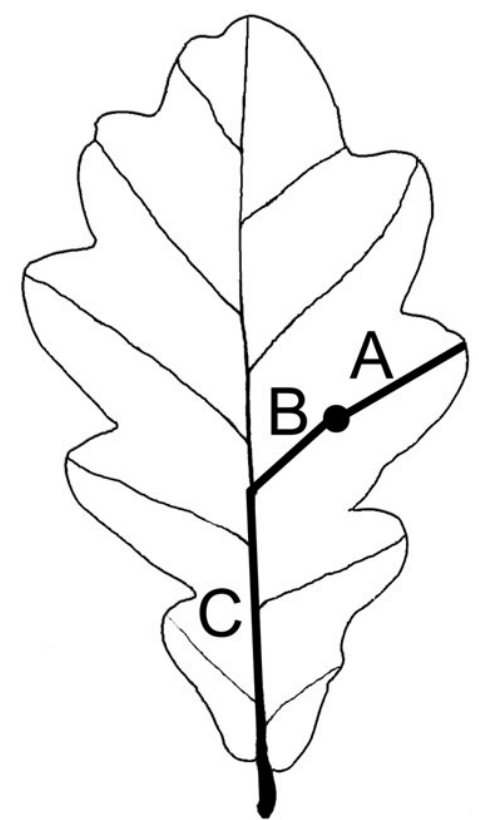

Fig. 1. Diagram showing the measurements made on oak leaves: $\mathrm{A}$ - distance along a vein from gall to leaf edge; $\mathrm{B}$ - distance along a vein from gall to main vein; $\mathrm{C}$ - distance along main vein from petiole to the lateral vein with the gall.

opportunity to examine all the leaves from the tree crowns. Galls of Cynips quercusfolii were found on almost half of the trees, and for this research we used 15 trees of different ages (37 -2 trees; $50-8$ trees; $79-2$ trees; $95-3$ trees). The heights of the trees were measured and grouped (five trees per class) into three height classes - (a) $<16 \mathrm{~m}$, (b) $16-20 \mathrm{~m}$ and (c) $>20 \mathrm{~m}$ (means and standard deviations for each class were $14.6 \pm 0.8$ $\mathrm{m} ; 16.8 \pm 0.4 \mathrm{~m} ; 24.3 \pm 1.7 \mathrm{~m}$, respectively). To divide the crowns into upper (exposed leaves) and lower (shaded leaves) levels, we measured SLA (specific leaf area $-\mathrm{cm}^{2} / \mathrm{g}$ ) at 5-9 positions in the crown depending on tree height. SLA is a very good indicator of light conditions experienced during leaf growth (Poorter, 2001). We did not confirm this relationship in this study, but based on this assumption, we classified leaves with a SLA less than the average as from the upper crown and those with a SLA greater than average as from the lower crown.

All the leaves from the trees were removed and weighed. All leaves with galls $(\mathrm{N}=192)$ that were produced by agamic females of Cynips quercusfolii were identified and also weighed. More than one gall was found on only two leaves. These leaves were retained in the analysis, but the smaller gall was omitted from the data. We also observed a few cases of galls of other species [Cynips longiventris Htg. or Neuroterus quercusbaccarum (L.)]. Due to the small number of galls of other species, we did not include interspecific competition as a factor in the analysis. Some of the leaves without galls (at least $100 \mathrm{~g}$ of fresh mass from each part of the crown; 5-9 samples per tree) were weighed, dried at $65^{\circ} \mathrm{C}$, and then weighed again in order to determine the total dry mass of leaves. To determine the area of 1659 leaves (72-192 per tree), including the 192 leaves with galls, and the distances (Fig. 1) along the vein from gall to leaf edge (A) and from gall to petiole $(\mathrm{B}+\mathrm{C})$, we used WinFolia Pro software (Regents Instruments Inc., Quebec, Canada). We used a calibrated scanner and WinFolia software to measure automatically the lengths (A, B and C) that were previously marked on the scanned leaves. Moreover, we recorded the number of particular veins with a gall (the first vein refers to the

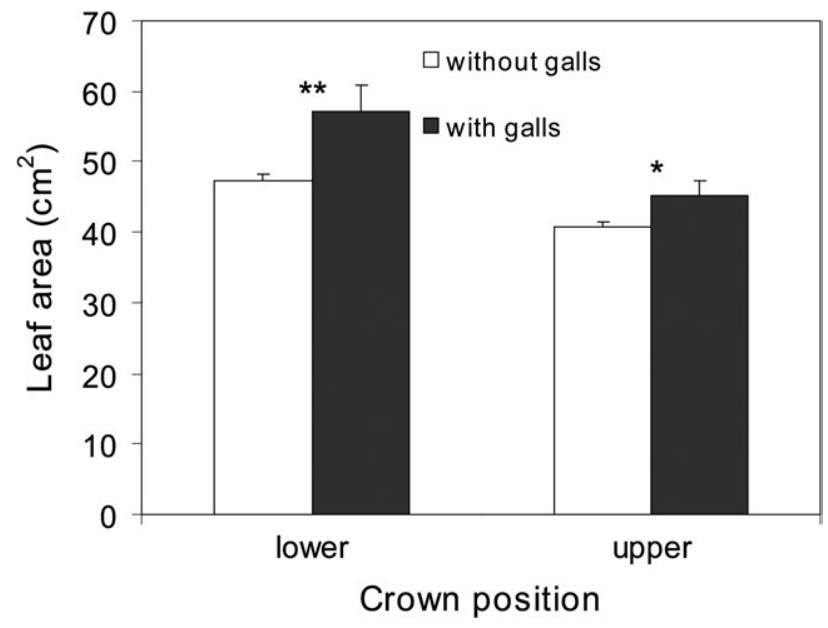

Fig. 2. Comparison of the areas of Quercus robur leaves (mean $\pm \mathrm{SE}$ ) with and without Cynips quercusfolii galls from the lower and upper parts of the crowns of trees $\left(^{*}-P<0.05\right.$, $* *-P<0.01)$.

vein next to the petiole). In order to test the hypothesis of a random distribution of galls on the veins of oak leaves, we counted the number of veins on the leaves with galls, recorded the location of the galls and used a chi-square test to verify statistical significance $(2 \times 8$ contingency table and log-likelihood ratio analysis)

Mixed model ANOVA was used to analyse the influence of tree height, crown position, and interaction between them on the number of galls. The number of galls is the sum for leaves from the upper or lower part of the crown of a tree. Trees were nested within a tree height class. Tree height class and crown position effects were considered to be fixed and the tree effect was considered to be random. Data was analyzed using Shapiro-Wilk test to test the assumption of normality. The Restricted Maximum Likelihood method was used for estimating the components of variance. Linear regression was used to characterize the relationship between leaf area and location of a gall on a leaf surface. The chi-squared test was used to compare the observed results of galls on particular veins with the expected results based on frequency of veins. To analyse the relationship between the leaf area (independent variable) and the presence of galls (dependent variable), we used simple logistic regression with outcome defined as 1 - presence of gall on leaf, 0 - lack of galls on leaf. For all statistical analyses JMP 7.0.2 (SAS Institute Inc. Cary, NC, USA) was used.

\section{RESULTS}

Only a small percentage of the oak leaves in this study had a gall. On the basis of the comparison of the total leaf mass of a tree and the mass of leaves with galls, we calculated that only $0.42 \%(0.05-1.56 \%)$ of the leaves had

TABLE 1. Mean (SE) number of Cynips quercusfolii galls in the lower and upper parts of the crowns of trees of different heights.

\begin{tabular}{lcc}
\hline \multirow{2}{*}{$\begin{array}{l}\text { Tree height class } \\
\mathrm{m})\end{array}$} & \multicolumn{2}{c}{ Crown position } \\
\cline { 2 - 3 } Below 16 & Lower & Upper \\
$16-20$ & $8.6(5.6)$ & $9.6(6.0)$ \\
Above 20 & $4.8(2.3)$ & $75.3(28.2)$ \\
\hline
\end{tabular}




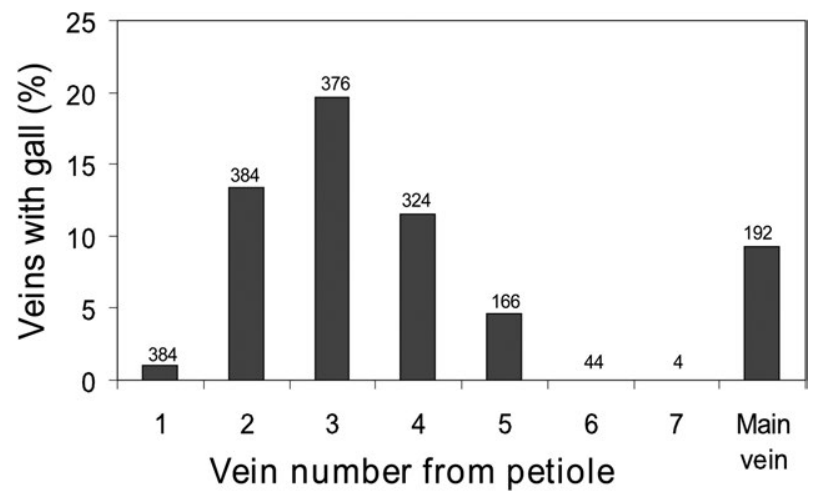

Fig. 3. Percentage of veins with galls (above each bar is total number of veins) for the 192 leaves of Quercus robur examined that had galls of Cynips quercusfolii.

galls (mean value for 15 trees). The number of galls did not differ significantly among the three height classes (Table 1 and 2) but did differ depending on the position within the crown with more galls in the upper, well-lit part of oak tree crowns. Furthermore, we noted a significant statistical interaction between the influence of crown position and tree height on gall presence. In trees of the middle height class, significantly more galls were located in the upper than in the lower part of the crown.

Regardless of their position within the crown, leaves with galls were significantly larger than those without (Fig. 2). Simple logistic regression analysis indicated a significant relationship between the presence of a gall and leaf area $\left[y=\mathrm{e}^{a+b x} /\left(1+\mathrm{e}^{a+b x}\right) ; x=\right.$ leaf area, $y=$ gall presence, $\left.a=2.50, b=-0.01 ; \chi^{2}=9.72 ; P=0.002\right]$.

The galls of $C$. quercusfolii were always located on the lateral or main veins on the under-surface of leaves. The leaves of $Q$. robur had 2-7 lateral veins and the majority of galls were on the second and third veins from the petiole (Fig. 3). The results refute the hypothesis that galls are distributed randomly on leaves $(\mathrm{N}=1874$ veins; $\left.\mathrm{DF}=7 ; \chi^{2}=107.0 ; P<0.0001\right)$.

Analysis of the location of $C$. quercusfolii galls $(\mathrm{N}=$ 192) on the leaves of pedunculate oak indicated that the galls were located at a fixed distance $(2.36 \pm 0.7 \mathrm{~cm})$ from the leaf edge. This distance was only slightly dependent on leaf area because only $6 \%$ of the variation in this feature can be explained by the size of the leaves (Fig. 4A). Meanwhile, the distance from the gall to the leaf petiole depended significantly on leaf size $\left(r^{2}=0.43\right.$; $P<0.0001 ; \mathrm{N}=192$ ) (Fig. 4B). The fact that the distances between galls and leaf edges were almost uniform in comparison with other parameters of the location of
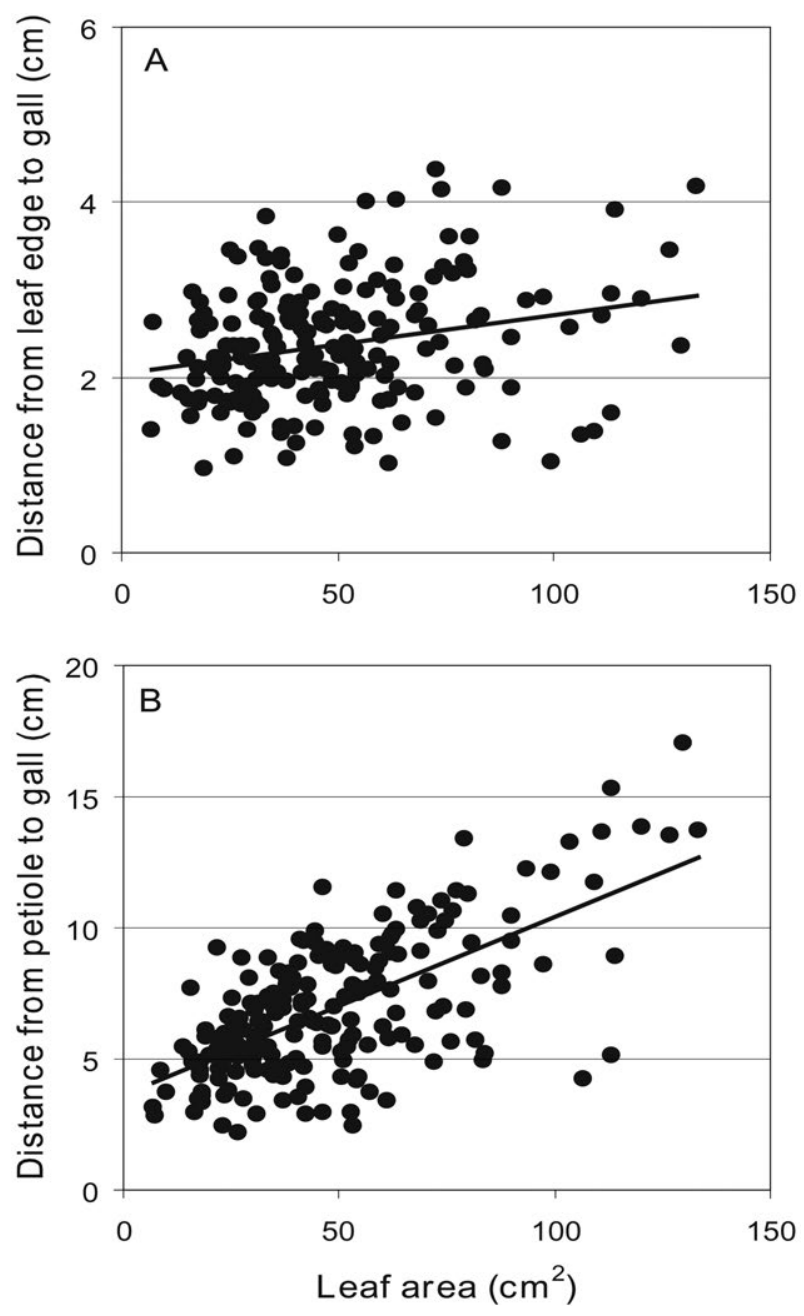

Fig. 4. Dependence of the distance from a Cynips quercusfolii gall to leaf edge (distance from leaf edge to gall $=2.06+0.006$ leaf area, $\left.\mathrm{r}^{2}=0.06 ; P<0.0009 ; \mathrm{N}=192\right)(\mathrm{A})$ and gall to the petiole (distance from petiole to gall $=3.68+0.067$ leaf area, $\mathrm{r}^{2}$ $=0.43 ; P<0.0001 ; \mathrm{N}=192)(\mathrm{B})$ on the area of a Quercus robur leaf.

galls on leaves resulted in a low coefficient of variation for this variable (Table 3).

\section{DISCUSSION}

Identification of the factors that determine the distribution of galls on particular host species is difficult given their rarity. In general, the percentage of oak leaves with galls is small. They do not have a negative influence on host population dynamics and rarely arouse interest in terms of research into the effects of insects on plants.

TABLE 2. Summary of the results of the ANOVA of the abundance of Cynips quercusfolii galls depending on tree height and crown position, and the interaction between them, showing degrees of freedom (df), mean squares (MS), mean squares for error $\left(\mathrm{MS}_{\text {Error }}\right), \mathrm{F}$ statistic and p-values.

\begin{tabular}{lccccc}
\hline Source & df & MS & MS Error & F & P \\
\hline Height Class (H) & 2 & 2540 & 1189 & 2.14 & 0.160 \\
Crown position (C) & 1 & 5505 & 709 & 7.77 & 0.016 \\
$\mathrm{H} \times \mathrm{P}$ & 2 & 3574 & 709 & 5.04 & 0.025 \\
Tree (Height Class) & 12 & 1189 & 709 & 1.68 & \\
\hline
\end{tabular}


TABLE 3. Mean, standard deviation (SD) and coefficient of variation $(\mathrm{CV})$ of oak leaf area and distances between gall and leaf edge (A), gall and main vein (B), petiole and base of vein with gall $(\mathrm{C})$ and data derived from calculations of other parameters.

\begin{tabular}{lccccc}
\hline Parameter & $\begin{array}{c}\text { Leaf area } \\
\left(\mathrm{cm}^{2}\right)\end{array}$ & $\begin{array}{c}\mathrm{A} \\
(\mathrm{cm})\end{array}$ & $\begin{array}{c}\mathrm{B} \\
(\mathrm{cm})\end{array}$ & $\begin{array}{c}\mathrm{C} \\
(\mathrm{cm})\end{array}$ & $\begin{array}{c}\mathrm{B}+\mathrm{C} \\
(\mathrm{cm})\end{array}$ \\
\hline Mean & 49.55 & 2.38 & 1.61 & 5.12 & 6.73 \\
SD & 24.21 & 0.71 & 1.07 & 2.06 & 2.35 \\
$\mathrm{CV}$ & 48.85 & 29.68 & 66.5 & 40.39 & 35.01 \\
\hline
\end{tabular}

However, occasionally, the damage caused by a gall can reduce plant performance (Madziara-Borusiewicz, 1982; Kato \& Hijii, 1997; Dhileepan \& McFadyen, 2001). In the present study, the small number of galls found (on $<$ $0.5 \%$ of the leaves) suggests a low effect on the host trees. This species of wasp is also reported to be uncommon in Southern Poland (Skrzypczyńska, 1994). There is a lack of published information on the fecundity of agamic females of $C$. quercusfolii, however, in view of the findings for other cynipid wasps it is likely that the females lay at most several hundred eggs (Sanderson, 1988; Shorthouse, 2010).

Our results did not support the hypothesis that galls are distributed evenly in crowns of trees as there were more galls in the upper parts of crowns. The distribution of galls can be influenced by many factors, including the availability of resources and the presence of natural enemies (Williams et al., 2001). The influence of resource availability can be explained by the ideal free distribution hypothesis (Fretwell \& Lucas, 1970), which predicts that the distribution of animals among patches of resources will minimize resource competition and maximize fitness, whereas the influence of enemies can be explained by the enemy free space hypothesis (Jeffries \& Lawton, 1984).

The fact that gall wasps only use a small percentage of the available foliage could suggest that their sparse distribution reduces the extent to which they are affected by predators and parasites. However, parasitism of galls is very common, often reaching $60-80 \%$ depending on the species of wasp (Eliason \& Potter, 2001; Csóka et al., 2004; Joseph et al., 2011). Parasitism is thus an important factor that can influence the size of populations of organisms that can initiate galls (Askew, 1961). In the case of insect-produced galls on oaks, more than 10 parasitoid and inquiline species can coexist with the developing insects (Sanver \& Hawkins, 2000; Redfern, 2011).

The plant vigour hypothesis predicts that female insect herbivores prefer to oviposit on more vigorous plants or plant parts in order to achieve higher offspring performance (Stone et al., 2002; Santos et al., 2011). Large leaves are often preferred by gall-forming females (Larsson, 1989), but this might simply be due to large leaves constituting a greater percentage of the total leaf area than small leaves (Gripenberg et al., 2007) and such a choice is not always beneficial for the performance of the offspring. In the case of the leaf-galling sawfly Pontania sp. on Salix sp., larval survival is best in small leaves (Clancy et al., 1993). The results of the present study indicate that agamic females choose large leaves for oviposition. In June, when the females lay eggs, the leaves are at their maximum size (Wesołowski \& Rowiński, 2006). Oak leaves varied markedly in area, with a coefficient of variation of almost $50 \%$, so the choice by females of the larger leaves of those available at a given location was unlikely to have occurred by chance. Our results might indicate that offspring have a greater chance to complete their development when in a large leaf. Even if the leaf is damaged by other herbivores, the probability that the gall will be affected is lower than on a small leaf.

Moreover, the galls were not located at random on leaves. The preference for the middle veins of leaves identified in this study is similar to that found by Sitch et al. (1988) in a study of a different gall wasp, Cynips divisa. The location of the particular site at which the eggs are laid on leaves is a key determinant of the survival and fertility of the offspring (Sitch et al., 1988). The choice by females of ovipositing in central veins could be similar to its choice of large leaves. Middle lobes of oak leaves are usually the largest, implying high inflow of nutrients and assimilates (Zwieniecki et al., 2002; Scoffoni et al., 2011), which is especially important in the initial stage of gall development (Harris \& Shorthouse, 1996). The surprising finding of an almost constant distance between the gall and the leaf edge (Fig. 3) may be explained by both the need to ensure a proper flow of nutrients and assimilates and probably by the mechanical properties of veins (e.g., optimal vein thickness for gall).

\section{CONCLUSION}

In summary, we show that the galls of $C$. quercusfolii are not evenly distributed in the crowns of oak trees and are more common in the upper part of the crown, especially in trees of medium height. Agamic females prefer large leaves and precisely choose the location on a leaf where to lay their eggs. This probably ensures that the developing gall obtains the required amount of nutrients and assimilates.

ACKNOWLEDGEMENTS. This research was supported by the Ministry of Science and Higher Education, Poland, project no. N N304 210737, and the General Directorate of State Forests in Warsaw, Poland, for the project "The carbon balance in biomass of major forest-forming tree species of Poland". We kindly thank L.E. Frelich (University of Minnesota, USA) for linguistic support and valuable comments on an early draft of this manuscript.

\section{REFERENCES}

Abrahamson W.G., Hunter M.D., Melika G. \& Price P.W. 2003: Cynipid gall-wasp communities correlate with oak chemistry. - J. Chem. Ecol. 29: 208-223.

AsKew R.R. 1961: On the biology of the inhabitants of oak galls of Cynipidae (Hym.) in Britain. - Trans. Soc. Br. Entomol. 14: 237-268.

Clancy K.M., Price P.W. \& Sacchi C.F. 1993: Is leaf size important for a leaf-galling sawfly (Hymenoptera, Tenthredinidae)? - Environ. Entomol. 22: 116-126.

Csóka G., Stone G.N. \& Melika G. 2004: Biology, ecology and evolution of gall-inducing Cynipidae. In Raman A., Schaefer C.W. \& Withers T.M. (eds): Biology, Ecology and Evolution 
of Gall-inducing Arthropods. Science Publishers, Enfield, NH, pp. 569-636.

Dhileepan K. \& McFadyen R.E.C. 2001: Effects of gall damage by the introduced biocontrol agent Epiblema strenuana (Lep., Tortricidae) on the weed Parthenium hysterophorus (Asteraceae). - J. Appl. Entomol. 125: 1-8.

Eliason E.A. \& Potter D.A. 2001: Spatial distribution and parasitism of leaf galls induced by Callirhytis cornigera (Hymenoptera: Cynipidae) on pin oak. - Environ. Entomol. 30: $280-287$.

Folliot R. 1964: Contribution à l'étude de la biologie des Cynipides gallicoles (Hyménoptères, Cynipoïdea). - Ann. Sci. Nat. (Zool.) (Paris) 12 Sér. 6: 407-564.

FRETwELL S.D. \& LuCAS H.L. JR. 1970: On territorial behaviour and other factors influencing habitat distribution in birds. I. Theoretical development. - Acta. Biotheor. 19: 16-36.

Gripenberg S., Morrien E., Cudmore A., Salminen J.P. \& RosLIN T. 2007: Resource selection by female moths in a heterogeneous environment: what is a poor girl to do? $-J$. Anim. Ecol. 76: 854-865.

Harris P. \& Shorthouse J.D. 1996: Effectiveness of gall inducers in weed biological control. - Can. Entomol. 128: 1021-1055.

Hood G.R. \& Oтт J.R. 2010: Developmental plasticity and reduced susceptibility to natural enemies following host plant defoliation in a specialized herbivore. - Oecologia 162: 673-683.

Horner J.D. \& Abrahamson W.G. 1992: Influence of plant genotype and environment on oviposition preference and offspring survival in a gallmaking herbivore. - Oecologia 90: 323-332.

JefFries M.J. \& Lawton J.H. 1984: Enemy free space and the structure of ecological communities. - Bot. J. Linn. Soc. 23: 269-286.

Joseph M.B., Gentles M. \& Pearse I.S. 2011: The parasitoid community of Andricus quercuscalifornicus and its association with gall size, phenology, and location. - Biodivers. Conserv. 20: 203-216.

Kampichler C. \& Teschner M. 2002: The spatial distribution of leaf galls of Mikiola fagi (Diptera: Cecidomyiidae) and Neuroterus quercusbaccarum (Hymenoptera: Cynipidae) in the canopy of a Central European mixed forest. - Eur. J. Entomol. 99: 79-84.

KARBAN R. 2007: Deciduous leaf drop reduces insect herbivory. - Oecologia 153: 81-88.

Kато K. \& HiлI N. 1997: Effects of gall formation by Dryocosmus kuriphilus Yasumatsu (Hym., Cynipidae) on the growth of chestnut trees. - J. Appl. Entomol. 121: 9-15.

Kolk A., Starzyk J.R., Kenelski S. \& Dzwonkowski R. 1996: Atlas of Harmful Forest Insects. Multico, Warsaw, 705 pp. [in Polish].

KUCZYŃSKi L. \& SKoRACKA A. 2005: Spatial distribution of galls caused by Aculus tetanothrix (Acari: Eriophyoidea) on arctic willows. - Exp. Appl. Acarol. 36: 277-289.

LARSSON S. 1989: Stressful times for the plant stress - insect performance hypothesis. - Oikos 56: 277-283.

Madziara-Borusiewicz K. 1982: Cynipidae (Hym.) as pests of oaks (Quercus sp.). - Sylwan 4: 21-30.

Nyman T., Paajanen R., Heiska S. \& Julkunen-Titto R. 2011: Preference-performance relationship in the gall midge Rabdophaga rosaria: insights from a common-garden experiment with nine willow clones. - Ecol. Entomol. 36: 200-211.
Poff A.C., Haynes K.J., Szymanski M., Back D., Williams M.A. \& CRONIN J.T. 2002: Bird predation and the host-plant shift by the goldenrod stem galler. - Can. Entomol. 134: 215-227.

POORTER L. 2001: Light-dependent changes in biomass allocation and their importance for growth of rain forest tree species. - Funct. Ecol. 15: 113-123.

Pujade-Villar J., Bellido D., Segú D. \& Melika G. 2001: Current state of knowledge of Heterogony in Cynipidae (Hymenoptera, Cynipoidea). - Ses. Entomol. ICHN-SCL 11[1999]: 87-107.

RedFern M. 2011: Plant Galls. Collins, London, 564 pp.

SANDERSON A.R. 1988: Cytological investigations of parthenogenesis in gall wasps (Cynipidae, Hymenoptera). - Genetica 77: 189-216.

Santos J.C., Tavares C.B. \& Almeida-Cortez J.S. 2011: Plant Vigor Hypothesis refuted: preference-performance linkage of a gall-inducing weevil on small-sized host plant resources. Braz. J. Biol. 71: 65-69.

SANVER D. \& Hawkins B.A. 2000: Galls as habitats: the inquiline communities of insect galls. - Basic Appl. Ecol. 1: 3-11.

Scoffoni C., Rawls M., McKown A., Cochard H. \& Sack L. 2011: Decline of leaf hydraulic conductance with dehydration: relationship to leaf size and venation architecture. - Plant Physiol. 156: 832-843.

SHORTHOUSE J.D. 2010: Galls induced by cynipid wasps of the genus Diplolepis (Hymenoptera: Cynipidae) on the roses of Canada's grasslands. In Shorthouse J.D. \& Floate K.D. (eds): Arthropods of Canadian Grasslands. Biological Survey of Canada, Ottawa, pp. 251-279.

Sitch T.A., Grewcock D.A. \& Gilbert F.S. 1988: Factors affecting components of fitness in a gall-making wasp (Cynips divisa Hartig). - Oecologia 76: 371-375.

SKRZYPCZYŃSKA M. 1994: Study on insects association causing galls on the leaves of Quercus robur L. in the Ojców National Park. Pradnik. — Prace Muz. Szafera 9: 225-230.

SkUHRAVY V. \& SkUhrava M. 1996: Betrachtung der Gallmücken (Diptera, Cecidomyiidae) an dominanten Forstgehölzen Eurasiens nach ihrem Schädlichkeitsgrad mit einigen besonderen taxonomischen Problemen. - J. Pest Sci. 69: $56-58$.

Stone G.N., Schonrogge K., Atkinson R.J., Bellido D. \& Pujade-VILlar J. 2002: The population biology of oak gall wasps (Hymenoptera: Cynipidae). - Annu. Rev. Entomol. 47: 633-668.

WesoŁowsKi T. Rowiński P. 2006: Timing of budburst and treeleaf development in a multispecies temperate forest. - For. Ecol. Manag. 237: 387-393.

Williams I.S., Jones T.H. \& Hartley S.E. 2001: The role of resources and natural enemies in determining the distribution of an insect herbivore population. - Ecol. Entomol. 26: 204-211.

Zargaran M.R., Safaralizadeh M.H., Pourmirza A.A. \& ValiZADEGAN O. 2011: Effect of cardinal directions on gall morphology and parasitization of the gall wasp, Cynips quercusfolii. - J. Insect Sci. 11: 1-10.

Zwieniecki M.A., Melcher P.J., Boyce C.K., SAck L. \& HolBROOK N.M. 2002: Hydraulic architecture of leaf venation in Laurus nobilis L. - Plant Cell Environ. 25: 1445-1450.

Received November 8, 2012; revised and accepted May 6, 2013 